\section{Clofarabine combined with etoposide and cyclophosphamide for refractory and multiple relapsed childhood B-cell precursor acute lymphoblastic leukemia: an experience of the Polish Pediatric Leukemia/Lymphoma Study Group}

๑) 2020 Polish Society of Hematology and Transfusion Medicine, Insitute of Hematology and Transfusion Medicine. Published by Sciendo. All rights reserved.
Article history:

Received: 19.04 .2020

Accepted: 29.05 .2020

Jacek Wachowiak ${ }^{1, *}$ Jan Styczyński², Joanna Owoc-Lempach³, Ewa Gorczyńska³, Agnieszka Zaucha-Prażmo ${ }^{4}$ Jerzy Kowalczyk ${ }^{4}$, Tomasz Szczepański Walentyna Balwierz ${ }^{6}$

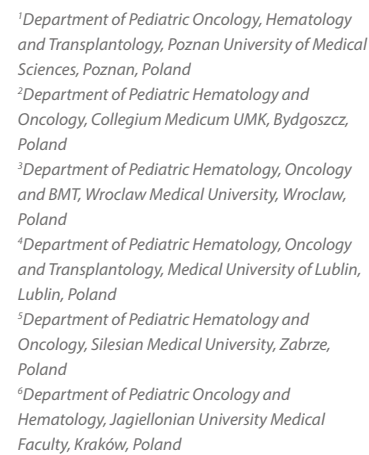

\section{Introduction}

Acute lymphoblastic leukemia (ALL) accounts for almost $30 \%$ of all childhood malignancies, i.e., ALL is the most frequent malignancy in pediatric population, and thus poses as the central problem of pediatric oncology. Approximately $80-85 \%$ of all childhood ALL cases originate from B-cell precursor (pB-ALL). Nowadays, as a result of long-standing global collaboration of pediatric oncologists, the first line treatment of childhood ALL assures 5-year event-free survival (EFS) for around $85 \%$ of patients. However, still there are significant differences between risk groups and subtypes of childhood ALL in terms of refractoriness or relapse rate, which amounts $15-20 \%$ and remains the most common cause of the first-line treatment failure [1, 2, 3].

Despite the intensified second-line chemotherapy, stratified and combined with allogeneic hematopoietic stem cell transplantation (allo-HSCT) according to the recognized risk factors, only $30-50 \%$ of all children experiencing the first relapse of ALL obtain its second long-term complete remission (CR) [2]. The treatment results in children with refractory or multiple relapsed ALL are even much worse, and thus there is an urgent need to offer them new, more effective salvage therapeutic approaches integrating combined chemotherapy based on new formulations of existing agents and new agents along with immunotherapeutic and molecularly targeted therapeutic modalities [2, 4].

Among newer chemotherapeutic agents, clofarabine (2-chloro-2'fluoro-deoxy-9-b-d-arabinofuranosyladenine), a second generation purine nucleoside analog, takes a special place due its antitumor activity mechanism as well as its therapeutic and safety profile. Namelly, clofarabine inhibits DNA polymerase a and ribonucleotide reductase along with disruption of mitochondrial membrane integrity with subsequent release of proapoptotic factors leading to the death of both dividing and nondividing lymphocytes [5]

In pediatric and adult patients suffering from refractory and multiple relapsed acute leukemia, phase I and II studies with clofarabine as a single agent have shown its activity with an overall remission rate of $20 \%$ in pediatric patients and without dose-limiting neurotoxicity characteristic for the first-generation nucleoside analogs (fludarabine and cladribine) $[6,7]$.

Later, initially in preclinical experiments and then in phase I and II studies, a synergistic antileukemic effect of clofarabine in combination with cyclophosphamide and etoposide has been shown, which is based on clofarabine-mediated inhibition of the repair of damage to the DNA induced by the last two agents [8,9]. From then several articles presenting results of combined chemotherapy consisted of clofarabine, etoposide, and cyclophosphamide (CEC) in children with refractory or multiple relapsed ALL have been published; however, presented results were ambiguous. Therefore, the Polish Pediatric Leukemia/Lymphoma Study Group (PPLLSG) decided to summarize its own experience in the field.

\section{Patients and methods}

This retrospective study evaluated eight pediatric patients (two females and six males) with advanced pB-ALL treated between 2015 and 2018 in four centers of the PPLLSG by combined chemotherapy consisted of CEC (Tab. I).

Patients aged $4.5-16$ years (median $=6$ years) at the time of $\mathrm{pB}-\mathrm{ALL}$ diagnosis and $5-18$ years (median $=9$ years) during the administration of CEC chemotherapy. 
Table I. Patients characteristics, clinical course of refractory or relapsed pre-B ALL and its response to CEC combined chemotherapy

\begin{tabular}{|c|c|c|c|c|c|c|c|c|c|c|c|c|}
\hline Patient & Sex & $\begin{array}{l}\text { Age at } \\
\text { CEC } \\
\text { (years) }\end{array}$ & $\begin{array}{l}\text { No. of prior } \\
\text { therapies }\end{array}$ & $\begin{array}{l}\text { Allo-HSCT } \\
\text { prior CEC }\end{array}$ & $\begin{array}{l}\text { Pre-B ALL } \\
\text { status } \\
\text { prior CEC }\end{array}$ & $\begin{array}{l}\text { No. of CEC } \\
\text { courses } \\
\text { (ind/cons) }\end{array}$ & $\begin{array}{c}\text { Response } \\
\text { to CEC }\end{array}$ & $\begin{array}{l}\text { Allo-HSCT } \\
\text { after CEC }\end{array}$ & $\begin{array}{l}\text { Duration of } \\
\text { CR (months) }\end{array}$ & Outcome & $\begin{array}{l}\text { Cause } \\
\text { of death }\end{array}$ & $\begin{array}{c}\text { Overall } \\
\text { survival } \\
\text { from CEC } \\
\text { (months) }\end{array}$ \\
\hline 1 & $\mathrm{~F}$ & 5 & 1 & No & $\begin{array}{l}\text { Refractori- } \\
\text { ness to first } \\
\text { line therapy }\end{array}$ & $3 / 0$ & $C R$ & Yes & 2 & Death & $\begin{array}{l}\text { Post allo-HSCT } \\
\text { CMV-IP and } \\
\text { MOF }\end{array}$ & 4.3 \\
\hline 2 & M & 10 & 2 & No & $\begin{array}{l}\text { First refrac- } \\
\text { tory } \\
\text { BM relapse }\end{array}$ & $0 / 1$ & $C R$ & Yes & 2.5 & Death & $\begin{array}{l}\text { Post allo-HSCT } \\
\text { relapse, pro- } \\
\text { gression }\end{array}$ & 4.5 \\
\hline 3 & M & 13 & 2 & No & $\begin{array}{l}\text { First refrac- } \\
\text { tory } \\
\text { BM relapse }\end{array}$ & $1 / 0$ & $C R$ & No & 1 & Death & $\begin{array}{l}\text { Infection } \\
\text { during the } \\
\text { course of } \\
\text { deep long- } \\
\text { term myelo- } \\
\text { suppression }\end{array}$ & 2 \\
\hline 4 & M & 18 & 2 & No & $\begin{array}{l}\text { First refrac- } \\
\text { tory } \\
\text { BM relapse }\end{array}$ & $1 / 0$ & $C R$ & Yes & 35 & $\begin{array}{l}\text { Alive } \\
\text { in } C R\end{array}$ & NA & $38^{*}$ \\
\hline 5 & M & 8 & 3 & No & $\begin{array}{l}\text { Second } \\
\text { refractory } \\
\text { BM/CNS } \\
\text { relapse }\end{array}$ & $1 / 0$ & $C R$ & Yes & 16 & $\begin{array}{l}\text { Alive after } \\
\text { post } \\
\text { allo-HSCT } \\
\text { relapse } \\
\text { treated } \\
\text { with CAR-T }\end{array}$ & NA & $42^{*}$ \\
\hline 6 & M & 18 & 3 & No & $\begin{array}{l}\text { Second } \\
\text { refractory } \\
\text { extramedul- } \\
\text { lary relapse }\end{array}$ & $0 / 2$ & $\begin{array}{l}\text { Refrac- } \\
\text { tory }\end{array}$ & No & NA & Death & Progression & 2.2 \\
\hline 7 & $M$ & 7.5 & 3 & Yes & $\begin{array}{l}\text { Second } \\
\text { refractory } \\
\text { BM relapse }\end{array}$ & $0 / 2$ & $C R$ & No & 3.5 & Death & $\begin{array}{l}\text { Infection } \\
\text { during the } \\
\text { course of } \\
\text { deep long- } \\
\text { term myelo- } \\
\text { suppression }\end{array}$ & 4.5 \\
\hline 8 & $\mathrm{~F}$ & 8 & 1 & Yes & $\begin{array}{l}\text { Post al- } \\
\text { lo-HSCT BM } \\
\text { relapse }\end{array}$ & $2 / 0$ & $C R$ & No & 2 & Death & $\begin{array}{l}\text { Infection } \\
\text { during the } \\
\text { course of } \\
\text { deep long- } \\
\text { term myelo- } \\
\text { suppression }\end{array}$ & 4.5 \\
\hline
\end{tabular}

CEC - clofarabine + etoposide + cyclophosphamide; allo-HSCT - allogeneic hematopoietic stem cell transplantation; ind/cons - induction/consolidation; BM - bone marrow; CMV-IP - cytomegalovirus interstitial pneumonia; MOF - multiorgan failure; NA - not applicable; * - censored at date of last known follow-up visit

Among the eight evaluated patients, one received CEC due to refractoriness to first line therapy (ALL IC-BFM 2009), three patients for first bone marrow relapse refractory to second line treatment (IntReALL 2010), three patients for second refractory relapse, and one patient for first bone marrow relapse that occurred 4 months after allo-HSCT given along with first line treatment of high-risk pB-ALL.

As an induction cycle, patients received clofarabine at a daily dose of $40 \mathrm{mg} / \mathrm{m}^{2}$ i.v. over $2 \mathrm{~h}$ for 5 days, followed by etoposide at a daily dose of $100 \mathrm{mg} / \mathrm{m}^{2}$ i.v. over $2 \mathrm{~h}$ for 5 days and cyclophosphamide at a daily dose of $440 \mathrm{mg} / \mathrm{m}^{2}$ i.v. over $1 \mathrm{~h}$ for 5 days.

Consolidation cycle consisted of the same agents as the ones used in induction cycle, which were administered for four consecutive days with the same daily doses given during induction. Prednisone was given a daily dose of $0.5 \mathrm{mg} / \mathrm{kg}$ for cytokine release syndrome prevention.

Of the eight evaluated children, five received 1-3 induction cycles of CEC therapy without any subsequent consolidation cycle, whereas the remaining three patients received 1-2 consolidation cycles alone.
All evaluated patients received anti-bacterial, anti-mycotic, and Pneumocystis jiroveci pneumonia prophylaxis.

Patients who achieved CR were given allo-HSCT if suitable donor was available and if there was no contraindications for allo-HSCT related to the clinical status of the patient.

Patient characteristics, administered treatment, and response to treatment are shown in table I.

\section{Results and discussion}

This is the first report on CEC chemotherapy results of children and adolescents with refractory/multiple relapsed ALL treated in centers of the PPLLSG. Admittedly the evaluated group of patients is small, however, it is homogeneous in terms of immunophenotype, because all patients suffered from $\mathrm{pB}-\mathrm{ALL}$.

Of the evaluated, as many as seven out of eight heavily pretreated patients with refractory pB-ALL achieved CR after CEC therapy, including three patients after one CEC induction cycle, one patient 
after two, another one after three induction cycles, and finally one patient obtained $\mathrm{CR}$ after one consolidation cycle and another one after administration of two consolidation cycles. Only one patient with refractory second extramedullary relapse (in bone) failed to achieve $\mathrm{CR}$ after two consolidation cycles and died due to progression of the disease.

Thus, the response to CEC observed in the evaluated pediatric patients confirmed significant anti-leukemic capability of the regimen, which was even better than overall response rate of $42-69 \%$ (median $=55 \%$ ) and CR rate of $18-52 \%$ (median $=38 \%$ ) reported by other authors [9-13].

In addition, four patients underwent allo-HSCT for consolidating the obtained CR. However, despite the high rate of good early response, only one out of seven patients who achieved $C R$ remains in CCR for 35 months. Among the remaining six patients, in two of them a subsequent relapse occurred despite $\mathrm{CR}$ consolidation with allo-HSCT (2.5 and 16 months after transplantation), four patients died due to infectious complications, including three patients after CEC regimen (at 2, 4.5, and 4.5 months of the regimen) during the course of prolonged myelosuppression, and one patient died 35 days after matched unrelated donor HSCT as a result of CMV interstitial pneumonia with respiratory insufficiency and multi-organ failure (MOF). Only two patients are still alive, including one in CCR for 38 months from CEC and the second one for 42 months from CEC now in fourth CR achieved with CAR-T cells after post-CEC and post allo-HSCT relapse. Thus, in our patients the long-term results were much poorer than those reported by Liu et al. [13] (EFS 38.5\% and OS 51.3\% at 12 months) and by Locatelli et al. [10] (OS 33\% at 18 months); however, other authors also found relapse/progression and infections occurring in course of prolonged neutropenia as major causes of treatment failures [9-13]. In addition, the IntReALL Group initially aimed at comparing the CEC regimen with the established ALL-REZ BFM regimen F1 and F2 for induction therapy of children with high risk (HR) relapse of ALL. A pilot study of the United Kingdom Group started in 2010 to confirm the feasibility of the regimen in the intended indication, however, revealed inferior EFS rates compared to the historical controls [14].

In contrast to deep and long-lasting myelosuppression with subsequent severe infections observed both in the evaluated patients and in patients reported by some other authors [8, 9, 11], the severe toxicity of organs, in particular, severe hepatoxicity, including sinusoidal obstruction syndrome (SOS) [8, 9], was not observed and none of the evaluated children died due to CEC regimen-related organ toxicity. Similar observations have been made by Locatelli et al. [10] and Miano et al. [12].

\section{Conclusions}

In the evaluated group of pediatric patients with refractory or multiple relapsed $\mathrm{pB}-\mathrm{ALL}$ the regimen consisted of CEC demonstrated significant early anti-leukemic activity in terms of obtained CR rate, but an incidence of treatment failure due to infectious complications as well as an incidence of subsequent relapse/progression, including post-transplant relapse, was very high and indicates, respectively, on deep, prolonged myelosuppression and low quality of CR after CEC regimen alone. Therefore, to achieve a significant improvement of long-term results in children with resistant and multiple relapsed pB-ALL, implementation and integration of novel treatment approaches are indispensable, including immunotherapy with CAR-T cells, blinatumomab or inotuzumab along with personalized, molecularly targeted drugs, and a consolidative allo-HSCT in selected patients $[4,15]$.

\section{Authors' contributions}

JW - interpretation of collected data and manuscript preparation. JOL, AZP - data collection. JS, TSz - data collection and critical revision. EG, JK, WB - critical revision.

\section{Conflict of interest}

Authors declare no conflict of interest relevant to this study.

\section{Financial support}

None.

\section{Ethics}

The work described in this article has been carried out in accordance with The Code of Ethics of the World Medical Association (Declaration of Helsinki) for experiments involving humans; EU Directive 2010/63/ EU for animal experiments; Uniform requirements for manuscripts submitted to biomedical journals.

\section{References}

[1] Pui C-H, Yang JJ, Hunger SP, et al. Childhood acute lymphoblastic leukemia: progress through collaboration. J Clin Oncol 2015;33:2938$-48$.

[2] Locatelli F, Schrappe M, Bernardo ME, Rutella S. How I treat relapsed childhood acute lymphoblastic leukemia. Blood 2012;120:2807-16.

[3] Zawitkowska J, Lejman M, Drabko K, et al. First-line treatment failure in childhood acute lymphoblastic leukemia: the Polish Pediatric Leukemia and Lymphoma Study Group experience. Medicine (Baltimore) 2020:99:e19241.
[4] Simioni C, Bergamini F, Ferioli M, Rimondi E, Caruso L, Neri LM. New biomarkers and therapeutic strategies in acute lymphoblastic leukemias: recent advances. Hematol Oncol 2020;38:22-33.

[5] Kanrarjian HM, Jeha S, Gandhi V, Wess M, Faderl S. Clofarabine: past, present and future. Leuk Lymphoma 2007;48:1922-30.

[6] Kantarjian HM, Gandhi V, Cortes J, et al. Phase II clinical and pharmacologic study of clofarabine in patients with refractory or relapsed acute leukemia. Blood 2003;102:2379-86. 
[7] Jeha S, Gaynon PS, Razzouk Bl, et al. Phase 2 study of clofarabine in pediatric patients with refractory and relapsed acute lymphoblastic leukemia. J Clin Oncol 2006;24:1917-23.

[8] Hijiya N, Gaynon P, Barry E, et al. A multi-center phase I study of clofarabine, etoposide and cyclophosphamide in combination in pediatric patients with refractory or relapsed acute leukemia. Leukemia 2009;23:2259-64.

[9] Hijiya N, Thomson B, Isakoff MS, et al. Phase 2 trial of clofarabine in combination with etoposide and cyclophosphamide in pediatric patients with refractory or relapsed acute lymphoblastic leukemia. Blood 2011;118:6043-9.

[10] Locatelli F, Testi AM, Bernardo ME, etal.Clofarabine, cyclophosphamide and etoposide as single-course re-induction therapy for children with refractory/multiple relapsed acute lymphoblastic leukaemia. Br J Haematol 2009;147:371-8.

[11] Trioche P, Nelken B, Michel G, et al. French "real life" experience of clofarabine in children with refractory or relapsed acte lymphoblastic leukemia. Exp Hematol Oncol 2012;1:39.
[12] Miano M, Pistorio A, Putti MC, et al. Clofarabine, cyclophosphamide and etoposide for the treatment of relapsed or resistant acute leukemia in pediatric patients. Leuk Lymphoma 2012;53:1693-8.

[13] Liu APY, Lee V, Li CK, Ha SY, Chiang AKS. Refractory acute lymphoblatic leukemia in Chinese children: bridging to stem cell transplantation with clofarabine, cyclophosphamide and etoposide. Ann Hematol 2016;95:501-7.

[14] Final Report Summary - INTREALL (International study for treatment of childhood relapsed ALL 2010 with standard therapy, systematic integration of new agents, and establishment of standardized diagnostic and Research) https://cordis.europa.eu/project/ id/278514/reporting.

[15] Jacoby E. The role of allogeneic HSCT after CAR T cells for acute lymphoblastic leukemia. Bone Marrow Transplant 2019;54:810-4. 